\title{
The Effects of Direct and Indirect Corrective Feedback on Accuracy in Second Language Writing
}

\author{
Abbas Mustafa Abbas ${ }^{1} \&$ Hogar Mohammed Tawfeeq ${ }^{1}$ \\ ${ }^{1}$ English Department, School of Basic Education, Sulaimani University, Kurdistan Region of Iraq \\ Correspondence: Hogar Mohammed Tawfeeq, English Department, School of Basic Education, Sulaimani \\ University, Kurdistan Region of Iraq. Tel: 964-770-156-4043. E-mail: hogar.tawfeeq@spu.edu.iq
}

Received: April 13, 2018 Accepted: May 14, 2018 Online Published: May 16, 2018

doi: 10.5539/elt.v11n6p33 URL: http://doi.org/10.5539/elt.v11n6p33

\begin{abstract}
The effectiveness of providing Corrective Feedback (CF) on L2 writing has long been a matter of considerable debate. A growing body of research has been conducted to investigate the value of various types of $\mathrm{CF}$ on improving grammatical accuracy in the writing of English as a second or foreign language. This article is mainly concerned with the role of Corrective Feedback (CF) in developing the L2 writers' ability to produce an accurate text, and argues that CF is considered to be one of the fundamental techniques in teaching second language (L2) writing. Bearing this in mind, it attempts to maintain the effectiveness of CF on the L2 students' abilities to develop the accuracy of their written output. This topic has recently produced a significant interest among both teachers and researchers in the areas of L2 writing and second language acquisition. A key issue to be addressed is the degree to which CF effectively helps the second language writers obtain long-term accuracy. Currently, the author of this paper has been conducting a PhD study on the effect of direct and indirect corrective feedback on the academic writing accuracy of Kurdish EFL university students, and the data was collected from writing testing samples (pre-test, post-test and delayed post-test) produced by105 undergraduate students of English department from two public universities. The results obtained from the study should have important implications for $\mathrm{L} 2$ writing practitioners and researchers.
\end{abstract}

Keywords: corrective feedback (CF), error feedback (EF), grammar correction, second language (L2), teacher feedback (TF)

\section{Introduction}

It is generally assumed that writing in the English language is one of the most difficult tasks for L2 writers to accomplish (Gedion, Tati \& Peter, 2016; Almasi \& Tabrizi, 2016). L2 learners generally require significant help when it comes to writing in English (Hyland, 2003). Bearing this in mind, L2 learners need a range of basic and complex linguistic, mechanical and rhetorical skills in order to be able to produce a coherent and accurate piece of writing (Almasi \& Nemat Tabrizi, 2016).

Therefore, providing Corrective Feedback (CF) on students' writing products is one of the strategies that can be used in teaching writing as a second or foreign language. However, the effectiveness of CF on the students' abilities to develop their writing accuracy has long been a subject of debate (Kim \& Kim, 2011). Even though this topic is of interest to both writing practitioners and researchers, the debate about the role of CF in helping L2 writers to become successful in self-editing is far from being settled (Tootkaboni \& Khatib, 2014).

Revewing a number of studies, the main aim of this article is to explain how CF in L2 teaching of English writing could be used to help students improve their accuracy in the long-term. This article is divided into two main sections. The first will introduce CF and will also list some of its types. In addition, it will include a theoretical review of ongoing argument for the benefits of CF in L2 writing. The second part will demonstrate the effective role of CF given by teachers to improve the L2 learners' writing accuracy. Furthermore, the efficacy of both direct and indirect $\mathrm{CF}$ is investigated in light of the findings of several studies on L2 writing error feedback. 


\section{Corrective Feedback in L2 Writing}

\subsection{An Overview of Corrective Feedback}

Writing is considered to be one of the crucial components of applied linguistics. With the act of writing in mind, what L2 writers do when they begin writing has acquired major significance in research in the 1970s. The researchers' interest was grounded on the basis that to develop the output of writing for the students, how a piece of writing is conceived should be taken into account (Hedge, 2000). The findings by Zamel (1983: 169 cited in Hedge, 2000) indicated that the writing strategies good writers might rely on are planning, "getting started", "re-reading" and revision. In other words, many studies (e.g. Kim \& Kim, 2011) attribute the learner' writing improvement to the role of corrective feedback given in the process-orientated writing while undertaking revision or subsequent writing. Hence, it has been argued that giving feedback is one of the mechanisms that teachers should use to encourage students as they revise writing (Saito, 1994 \& Zhang, 1995).

There is not a collectives agreement on one definition for corrective feedback. Feedback is widely defined as the response that peers, teachers, or computers provide for the learner of writing in the form of either oral or written types (Hyland, 2002). In contrast to Truscott's (1996, p. 238) thesis claiming that "grammar correction has no place in writing courses and should be abandoned" it is "ineffective" and "has harmful effects", several studies emphasized the efficacy of corrective feedback. For instance, Ur (1991, p. 242) defines feedback in the setting of teaching as, 'The information that is given to the learner about his or her performance of a learning task, usually with the objective of improving this performance.' Echoing this assumption, it is also designated by Mubarak $(2013$, p. 54) as oral or written comments given by teachers about students' writing to empower their performance in writing accuracy.

Feedback is also defined by Azzaro \& Rice (2010) as another crucial source of information for learners to "inform them about the success of their communication and help them focus on production or comprehension ... and therefore enhances learning" (p. 51). Pedagogically speaking, Brookhart (2017, pp. 1-2) considers feedback as "an important component of the formative assessment process" that provides information to teachers and students which can be utilized as a "powerful" learning tool if it is "comprehensible" and "constructive".

Fundamentally, feedback falls into two major independent classes: "assessment" and "correction" (Ur, 1991, p. 242). Of these, there is more emphasis placed on the latter in this article because, according to (ibid.), the teacher provides information on what the student did "right" along with what they did "wrong", and "why". Silvia and Matsuda (2002) believe that feedback can be a part of grammar instruction, which may involve "direct correction" by the teacher or "recasts" that clarifies the lesson. They note that students should be allowed to make errors by being given them rules without making plain any exceptions. This makes them overgeneralise the rules and repeat errors. However, they might comprehend the exceptions very easily when they are provided with them to notice through corrective feedback.

\subsection{Different Types of Corrective Feedback}

Over the past decades, there has been a tendency for scholars to focus on investigations such as the efficacy of different types of feedback on L2 writing accuracy in order to account for the fact that one type of feedback outweighs others (Bitchener \& Knoch, 2010; Ghandi, \& Maghsoudi, 2014). In light of teacher-student interaction, teacher feedback (TF) can be classified into some major types: "electronic", "conference-based" and written (Goldstein, 2002, p. 186).

However, many researchers claim that despite the students' stated preferences in teacher feedback, its effectiveness has not yet settled on the L2 writers' improvement in both the short-term and the long-term (Ferris, 1997; Conrad \& Goldstein, 1999 cited in Hyland \& Hyland, 2006, p.3).

This article probes their claim and indicates that other scholars such as Leki (1991); Saito (1994); Zhang (1995) cited in (Hyland and Hyland, 2006, p. 3) argue that L2 writers significantly prioritize TF and value it more greatly than any other feedback types, for instance peer feedback (PF) and oral feedback (OF). Strengthening this view, the results of a study by Bitchener and Knoch (2010) indicate that providing teacher written correction supplemented by meta-linguistic explanation tend to be more preferable and productive for long-term accuracy.

With respect to different types of $\mathrm{CF}$, a number of research studies have been recently conducted to examine the level of effectiveness of each type on the L2 writers' adaption of teacher correction. It might be exactly the case in the distinction between direct and indirect CF. For instance, Ellis $(2009$, p. 98$)$ identified a number of primary strategies for giving feedback: direct and indirect CF, "metalinguistic" CF, "focused versus unfocused" CF, electronic CF and "reformulation".

This article will briefly explain these types of CF and address the difference between direct and indirect $\mathrm{CF}$ and 
their influences on students' performance. Ferris (2006, p. 83) clarify that indirect method is more beneficial as it obliges learners to involve in "guided learning" and "problem-solving". In contrast, direct CF is only desirable for the lower level students of L2 writing due to their lack of adequate linguistic knowledge. As far as proficiency is concerned, it slows down the learning process and it is not useful for long-term learning and memory. Alternatively, simply identifying the error in the text could assist learners to seek for the correct form.

Ellis (2009, p. 100) indicates that "Metalinguistic" CF provides feedback by giving explicit notes about the types of the errors, whether by placing error abbreviation codes close to the error by the teacher or gives some remarks about the type of the error that the student has made. Another method of feedback is "Focused versus Unfocused" CF. Learners may tend to prefer the former as the teacher chooses certain error categories, such as only article error, for correction.

A considerable number of research studies argues for feedback to be highly focused as they believe more gains are expected (Shen, 2007; Bitchener \& Knoch, 2010). In agreement with the proponents of this feedback type, L2 writers might receive assistance more from "Focused" method, because they can easily pinpoint the nature of their errors and take more care in their future level of writing. Consequently, this is likely to help students in long-term development, but in the "Unfocused" CF every single error will be identified with correction. There is another line of literature that claims the effectiveness of this kind of feedback for improving the student writing' accuracy (Chandler, 2003; Bitchener, Young \& Cameron, 2005). Although these two positions are still competing, no conclusive evidence has been established for the productivity of either type.

Regarding electronic $\mathrm{CF}$, students would receive $\mathrm{CF}$ from e-sources or electronic means. There is no sufficient evidence to show the effects of electronic CF in L2 writing. For example, Goldstein and Kohls (2006, cited in Goldstein, 2002, p. 186), emphasize the fact that giving error feedback electronically does not play a significant role in doing so. On the other hand, Ferris (2003), cited in (ibid., p. 186), claims that this type of feedback would provide students with a larger amount of feedback, but it is not yet clear whether it is better than the others or not.

The final method is "Reformulation"; this strategy will help students reconstruct their writings and correct errors until they will reach a good level (Ellis, 2009, p. 103). Furthermore, Hedge (2000, p. 313) maintains that "reformulation is a useful procedure when students have produced a first draft and are moving on to look at more local possibility for improvement".

\section{Direct and Indirect Corrective Feedback}

\subsection{The Effectiveness of CF on the Accuracy of L2 Learners' Writing}

Instructing L2 writing learners and giving successful CF on their performance are likely to be the two essential tasks of teachers in classrooms. In this section, I will deal with the effects of CF on the students' ability to be more accurate in their next pieces of writing. Whether CF has positive or negative impacts on the accuracy of L2 writers is debatable (Mubarak, 2013). The debate on the usefulness of CF in L2 writing dates back to 1996 when Truscott (1996) published an article postulating that teachers should avoid correcting grammatical errors in L2 writing because of its potentially harmful effects. His argument draws from the assumption that students' improved ability in writing due to corrective feedback cannot be seen as evidence of learning and does not assure that they would be able to produce a new piece of writing accurately.

Supporting this view, there are scholars (for example, Hartshorn, 2008) who claim that CF does not make a significant contribution to writing accuracy. In response to this claim, Ferris (1999) criticises Truscott's proposition, pointing out in line with the findings of many studies (Ferris, 2003; Sheen, 2007; Chandler, 2003) that giving an appropriate type of CF by the teacher plays an indispensable role in sustaining the students' self-correction in their subsequent writing.

On the one hand, there are researchers who have taken a position against CF by saying that correcting errors are "unnecessary", "counterproductive", and even "harmful" (for instance, Truscott, 1996, 1999 cited in Larsen-Freeman, 2003, p. 124). Moreover, the opponents of error correction in L2 acquisition believe that the teacher's CF causes students to be stressed, which negatively influences their learning (Larsen-Freeman, 2003).

Similarly, Hartshorn (2008) questions the validity of CF in making the L2 writers accurate in their future pieces of writing. He states that any approach of CF is less productive when the students' papers are many pages in length. He supports the claim by the paper's inclusion of large amount of errors that hinder both the teacher's efforts to identify them and the students' to make great use of the correction in their subsequent papers.

Furthermore, Hartshorn claims, the paper requiring correction and the extent of the teacher's tips are very time-consuming. Accordingly, the teacher may need some days before they will be able to return feedback to 
students. Likewise, a greater amount of time is necessary for students to make revision before the latest draft is given to the teacher. Eventually, neither teachers nor student end up doing their task properly. According to this argument, although CF could result in the "error-free paper", it is not as helpful in allowing L2 writers to write more accurately in their new piece of writings.

This claim is supported by some studies, for example Truscott and Hsu (2008) along with Nunan (1991) who believe that a considerable amount of feedback given by teachers might be "automatic" to some extent, and its eventual impact on the students is uncertain. Their claim has also been partially supported by Hyland's (2002) study who conducted a longitudinal research on the effects of feedback on the L2 learners writing in two classes. The results demonstrated that the feedback did not appear to have a lasting effect as the teachers focused on form in giving feedback.

Above all, in his research, Truscott (2007, p. 270) makes a controversial claim by concluding in his study, "The best estimate is that correction has a small harmful effect on students' ability to write accurately, and we can be 95\% confident that if it actually has any benefits, they are very small." These negative findings about the achievement of feedback groups are possibly biased, mainly with respect to grammar errors.

On the other hand, it could be argued that supplying students with CF is a primary function of teaching. Although the criticism of CF might have value in L1 teaching context, it may be unlikely the case in L2 learning, as the non-native students, particularly adults, expect to be given $\mathrm{CF}$ to reduce grammatical and spelling errors. Ferris $(1999$, p. 2) lends further support to this notion by describing Truscott's $(1996$, p. 328) conclusion as "premature" and "overly strong" that says, "Grammar correction has no place in writing courses and should be abandoned".

However, it can be noticed the gap in recent research on the effect of CF on reducing writing errors such as spelling and punctuation, which might be of L2 writers' major problems. This could be evidenced by research studies such as (Master, 1995; White et al., 1991 cited in ibid., p. 4) which discount Truscott's debate on CF, emphasizing that "form-focused" feedback is seen effective, particularly when followed by classroom instruction.

Further evidence in favour of feedback can be found in other studies, for instance, Hyland and Hyland (2006) consider feedback to have a fundamental role in teaching context for improving the learners' ability to write, and its impact has been clear on the L2 learners' writing.

Additionally, recent research on CF in L2 writing classes (such as, Fazio, 2001; Bitchener, 2008; Hartshorn, 2008 ) has come up with similar results in a study whose feedback group outperformed no feedback group. Their findings were supported by Ferris and Roberts (2001) whose study on 72 university ESL learners with different abilities to self-correct their papers through which they were tested with three various forms of feedback-errors marked with codes, only underlining and no feedback at all.

In other words, these results seem to challenge claims from researchers such as Truscott (2007) who have reported that $\mathrm{CF}$ is not supportive for developing the grammatical accuracy of L2 writing. In agreement with this side of the debate, therefore, it could be said that it is necessary for the L2 writers to receive CF with commentaries by the teacher to prepare for later revision. This argument is evidenced by (Bitchener, 2008) in his longitudinal study of the efficiency of written $\mathrm{CF}$ on a specific grammar topic to 75 pre-intermediate overseas ESL learners in Auckland, New Zealand, which dealt with 4 different CF groups. By analogy with the control group that received no $\mathrm{CF}$, the study indicated the accuracy of students in their later writing tests.

In conclusion, this paper is in agreement with the application of CF in L2 writing classrooms due to the evidence that even those who question the productivity of CF tend not to definitely disprove its advantages in the short term. Nonetheless, one can assume that in order for the CF to have a clear benefit, other strategies could be taken into account. For instance, differential feedback would be better assigned to different level of students, as well as commentary given by the teacher, as exemplified by the use of direct and indirect CF to more or less proficient students which will be discussed in the following section.

This outcome receives support from the finding by (Ferris, 2004, p. 59) who affirms that, "There is a variety options for error-feedback -from direct correction...to indirect approach- from which the teacher must choose, again bearing in mind the needs of the students and goals of the writing course and task." Thus, it is suggested that there is a need for future study to investigate the influences of CF more explicitly.

\subsection{The Effects of Direct and Indirect CF on Accuracy in L2 Writing}

How teachers provide correction for L2 learners' writing is an interesting subject both by researchers and teachers. As mentioned earlier, the aim of this article is to compare the difference effect of two main types of 
feedback direct and indirect on students' grammatical accuracy in new pieces of writings in light of recent studies.

Ellis (2009, p. 97) maintains that the correct use of CF in a "systematic" way is fundamental for both discovering whether written CF is constructive and, if it is, what type of CF is the most "effective". Ellis' study (2009, p. 99) reveals that in the direct $\mathrm{CF}$, "The teacher provides the student with the correct form (through) crossing out an unnecessary word..., inserting a missing word..., and writing the correct form above or near to the erroneous form." By comparison, ibid., (2009, p. 100) notes that "indirect CF involves indicating that the student has made an error without actually correcting it."

Many scholars (Bitchener, Young \& Cameron, 2005; Bitchener \& Knoch, 2010; Almasi, 2016) examine the effectiveness of different feedback types, especially between direct and indirect CF on L2 students' development in writing. This perspective has been possibly measured by the students' proficiency. For example, Ferris and Roberts (2001) believe that direct CF is likely more useful than indirect CF with less-proficient L2 writers. This argument may be convincing as less-competent learners need to be more provided with explicit guidance to better correct their errors. Despite this advantage, direct CF may not contribute to continuing improvement as it requires little effort on the part of the learner (Ellis, 2009). Conversely, Van Beuningen et al. (2008) claim that direct CF can help L2 writers make both short-term and long-term accuracy. This outcome is congruent with the Hashemnezhad and Mohammadnejad' (2012) study conducted on eighty Iranian EFL proficient students whose writing ability developed in new pieces of writing because of direct feedback than indirect one.

The evidence by these studies is not clear-cut as there have been many studies showing conflicting results of the effectiveness of direct CF in helping L2 learners completely self-edit in their subsequent writing. This argument is consistent with a great deal of empirical studies (for example, Erel, 2007; Liu, 2008). Liu' (2008) study investigating two feedback types -direct and indirect- on 12 university ESL learners' capacity to self-correct their essays demonstrated that despite the students' error reduction made by direct CF in the initial draft, their accuracy did not improve in their new papers. Similar results were found by Erel' (2007) research on 37 university students in an Turkish university indicating that the indirect coded feedback group outperformed the direct feedback group in term of the number of mistakes made.

Although there is a debate over the effect of indirect CF on students' ability to self-edit in subsequent drafts, it could be maintained that it is more effective on improving writing accuracy than direct CF. The study by Truscott and Hsu (2008) on 47 EFL graduates, 38 females and 9 males, from a university in Taiwan, indicated that "Improvements made during revision are not evidence on the productiveness of correction for improving learners' writing ability". Nevertheless, their finding was rebutted by Greenslade and Félix-Brasdefer (2006) who considered indirect $\mathrm{CF}$ as effective in enabling learners to generate considerably accurate compositions.

It can be argued that L2 learners make a great deal of progress in accuracy with the help of indirect indication of errors by the tutor as they should involve themselves in deeper processing to find the corrected forms. This assumption is supported by some studies: (Ellis, 2009; Liu, 2008; Roberts \& Ferris, 2001; Ji, 2015). For example, Ji's study on Chines learners targeting seven treatable errors concluded that the participants using indirect feedback outperformed a self-correction of their post-test and a new writing on the delayed post-test by reducing morphological errors. This is a potential indication of the long-term effectiveness of indirect error correction on the improvement of writing accuracy when teachers indicate the errors location and provide error codes.

In summary, it could be argued that the L2 learners can benefit from teacher written feedback to develop their accuracy in writing in line with Hyland's (2002) findings of a longitudinal study on the effects of feedback on L2 learners' writing, which revealed that the participants found teacher feedback provided during redrafting process valuable. Further, one may reach a plausible conclusion that L2 learners need indirect CF in order to independently edit their future drafts and make long-term improvement in accuracy.

\section{Conclusion}

Many research studies on corrective feedback in L2 writing have examined the correlation between error correction and writing performance. The findings of some researches concerning this issue have argued against the role of grammar correction in improving writing performance, especially grammatical accuracy (e.g. Truscott, 1996; Truscott and Hsu, 2008). However, there are considerable research studies that argue in favour of the effect of grammar correction on improving writing (Mohammadnejad, 2012; Ferris and Bitchener, 2008; Beuningen et al., 2008; Roberts, 2001). As mentioned earlier, the debate about the role of grammar correction in helping L2 writers to self-edit their composition is still continuous.

Providing effective feedback is a major issue for writing tutors and a matter of debate for L2 writing researchers. 
Although, some studies on L2 writing have challenged the effectiveness of written TF for developing students' ability to self-correct their texts, there are research-based evidence on the role of giving CF, especially indirect, in improving L2 learners' accuracy in writing. As far as the long-term effectiveness of indirect corrective feedback is concerned, writing tutors would be encouraged to give indirect CF over the course of period of time, a semester for instance, to assist L2 writers in developing their writing accuracy. It can be said that they should also provide focused $\mathrm{CF}$, as unfocused $\mathrm{CF}$ may be less effective due to being too time-consuming for the teacher and making the students overloaded.

However, further longitudinal studies of the effects of both direct and indirect corrective feedback on L2 students' writing accuracy in classroom are necessary to confirm these plausible conclusions about the role of indirect feedback in helping students to self-edit in new pieces of writing.

\section{References}

Almasi, E., \& Tabrizi, A. R. N. (2016). The effects of direct vs. indirect corrective feedback on iranian EFL learners' writing accuracy. Journal of Applied Linguistics and Language Research, 3(1), 74-85.

Azzaro, G., \& Rice, R. (2010). Error, feedback, negotiation: Technological and humanistic ways. In Errors in the second language classroom: Corrective feedback (pp. 47-70).

Bitchener, J. (2008). Evidence in support of written corrective feedback. Journal of second language writing, 17(2), 102-118. https://doi.org/10.1016/j.jslw.2007.11.004

Bitchener, J., \& Knoch, U. (2010). Raising the linguistic accuracy level of advanced L2 writers with written corrective feedback. Journal of Second Language Writing, 19(4), 207-217. https://doi.org/10.1016/j.jslw.2010.10.002

Bitchener, J., Young, S., \& Cameron, D. (2005). The effect of different types of corrective feedback on ESL student writing. Journal of second language writing, 14(3), 191-205. https://doi.org/10.1016/j.jslw.2005.08.001

Bjork, R. A. (1989). Retrieval inhibition as an adaptive mechanism in human memory. In H. L. Roediger III, \& F. I. M. Craik (Eds.), Varieties of memory \& consciousness (pp. 309-330). Hillsdale, NJ: Erlbaum.

Brookhart, S. M. (2017). How to give effective feedback to your students. ASCD.

Chandler, J. (2003). The efficacy of various kinds of error feedback for improvement in the accuracy and fluency of L2 student writing. Journal of second language writing, 12(3), 267-296. https://doi.org/10.1016/S1060-3743(03)00038-9

Ellis, R. (2008). A typology of written corrective feedback types. ELT journal, 63(2), 97-107. https://doi.org/10.1093/elt/ccn023

Erel, S., \& Bulut, D. (2007). Error treatment in L2 writing: A comparative study of direct and indirect coded feedback in Turkish EFL context. Sosyal Bilimler Enstitüsü Dergisi Sayl, 22(1), 397-415.

Fazio, L. L. (2001). The effect of corrections and commentaries on the journal writing accuracy of minority-and majority-language students. Journal of second language writing, 10(4), 235-249. https://doi.org/10.1016/S1060-3743(01)00042-X

Ferris, D. (1999). The case for grammar correction in L2 writing classes: A response to Truscott (1996). Journal of second language writing, 8(1), 1-11. https://doi.org/10.1016/S1060-3743(99)80110-6

Ferris, D. R. (2004). The "grammar correction" debate in L2 writing: Where are we, and where do we go from here?(and what do we do in the meantime...?). Journal of second language writing, 13(1), 49-62. https://doi.org/10.1016/j.jslw.2004.04.005

Ferris, D. R. (2006). Does error feedback help student writers? New evidence on the short-and long-term effects of written error correction. Feedback in second language writing: Contexts and issues, 81104.

Ferris, D., \& Roberts, B. (2001). Error feedback in L2 writing classes: How explicit does it need to be?. Journal of second language writing, 10(3), 161-184. https://doi.org/10.1016/S1060-3743(01)00039-X

Gedion, A., Tati, J. S., \& Peter, J. C. (2016). A Syntactic Errors Analysis in the Malaysian ESL Learners' Written Composition. Journal of Applied Linguistics and Language Research, 3(6), 96-104.

Ghandi, M. and Maghsoudi, M. (2014) The Effect of Direct and Indirect Corrective Feedback on Iranian EFL Learners' Spelling Errors. English Language Teaching, 7(1), 53-61. https://doi.org/10.5539/elt.v7n8p53

Goldstein, L. (2006). Feedback and revision in second language writing: Contextual, teacher, and student 
variables. Feedback in second language writing: Contexts and issues, 185-205. https://doi.org/10.1017/CBO9781139524742.012

Greenslade, T. A., \& Felix-Brasdefer, J. C. (2006). Error correction and learner perceptions in L2 Spanish writing. In Selected Proceedings of the 7th Conference on the Acquisition of Spanish and Portuguese as First and Second Language (pp. 185-194).

Hartshorn, K. J. (2008). The effects of manageable corrective feedback on ESL writing accuracy. Brigham Young University.

Hashemnezhad, H., \& Mohammadnejad, S. (2012). A case for direct and indirect feedback: The other side of coin. English Language Teaching, 5(3), 230. https://doi.org/10.5539/elt.v5n3p230

Hedge, T. (2001). Teaching and learning in the language classroom (Vol. 106). Oxford,, UK: Oxford University Press.

Hyland, K. (2003). Second language writing. Ernst Klett Sprachen. https://doi.org/10.1017/CBO9780511667251

Hyland, K., \& Hyland, F. (2006). Contexts and issues in feedback on L2 writing: An introduction. Feedback in second language writing: Contexts and issues, 1-19. https://doi.org/10.1017/CBO9781139524742.003

Ji, X. (2015). Error correction in college EFL writing instruction: Students' expectations and correction effects. The Journal of AsiaTEFL, 12(1), 117-140.

Kim, K., \& Kim, K. (2011). Grammar Correction in a Second Language (L2) Process-Oriented Composition Classroom. National Teacher Education Journal, 4(4).

Larsen-Freeman, D. (2003). Teaching language: From grammar to grammaring. Heinle \& Heinle Pub.

Liu, Y. (2008). The effects of error feedback in second language writing. The Arizona Working Papers in Second Language Acquisition and Teaching, 15, 65-79.

Mubarak, M. (2013). Corrective feedback in L2 writing: A study of practices and effectiveness in the Bahrain context (Doctoral dissertation, University of Sheffield).

Nunan, D. (1991). Language teaching methodology (Vol. 192). New York: prentice hall.

Saito, H. (1994). Teachers' practices and students' preferences for feedback on second language writing: A case study of adult ESL learners. TESL Canada journal, 11(2), 46-70. https://doi.org/10.18806/tesl.v11i2.633

Sheen, Y. (2007). The effect of focused written corrective feedback and language aptitude on ESL learners' acquisition of articles. Tesol Quarterly, 41(2), 255-283. https://doi.org/10.1002/j.1545-7249.2007.tb00059.x

Silvia, T. \& Matsuda, P. (2002). Language skills and assessment: Writing. In N. Schmitt (Ed.), An introduction to applied linguistics (pp. 232-246). Oxford: Oxford University press.

Tootkaboni, A. A., \& Khatib, M. (2014). The Efficacy of Various Kinds of Error Feedback for Improvement in the Writing Accuracy of Iranian EFL Learners. Bellaterra Journal of Teaching \& Learning Language \& Literature, 7(3), 30-46.

Truscott, J. (1996). The case against grammar correction in L2 writing classes. Language learning, 46(2), 327-369. https://doi.org/10.1111/j.1467-1770.1996.tb01238.x

Truscott, J. (2007). The effect of error correction on learners' ability to write accurately. Journal of second language Writing, 16(4), 255-272. https://doi.org/10.1016/j.jslw.2007.06.003

Truscott, J., \& Hsu, A. Y. P. (2008). Error correction, revision, and learning. Journal of second language writing, 17(4), 292-305. https://doi.org/10.1016/j.jslw.2008.05.003

Ur, P. (1996). A Course in Language Teaching: Practice and Theory, Cambridge Teacher Training \& Development Series.

Van Beuningen, C. G., De Jong, N. H., \& Kuiken, F. (2008). The effect of direct and indirect corrective feedback on L2 learners' written accuracy. ITL International Journal of Applied Linguistics, 156, 279-296. https://doi.org/10.1075/itl.156.24beu

Zhang, S. (1995). Reexamining the affective advantage of peer feedback in the ESL writing class. Journal of second language writing, 4(3), 209-222. https://doi.org/10.1016/1060-3743(95)90010-1 


\section{Copyrights}

Copyright for this article is retained by the author(s), with first publication rights granted to the journal.

This is an open-access article distributed under the terms and conditions of the Creative Commons Attribution license (http://creativecommons.org/licenses/by/4.0/). 